Article

\title{
Roma Identity as an Expert-Political Construction
}

\author{
Mihai Surdu ${ }^{1}$ and Martin Kovats ${ }^{2, *}$ \\ ${ }^{1}$ Institute of Advanced Studies, Central European University, 1051 Budapest, Hungary; E-Mail: surdu@policy.hu \\ ${ }^{2}$ Independent Researcher, E-Mail: martinkovats@netscape.net \\ * Corresponding author
}

Submitted: 11 February 2015 | In Revised Form: 10 May 2015 | Accepted: 20 May 2015 |

Published: 29 September 2015

\begin{abstract}
The creation of an EU Framework for national Roma integration strategies (2011) marks a significant step in the politicisation of Roma identity by ensuring a further increase in the number of initiatives, projects and programmes explicitly targeting Roma. The Framework itself is part of a process that began with postcommunist transition and which has produced historically unprecedented levels of Roma political activism along with a proliferation of national and transnational policy initiatives focussed on Roma identity. In seeking to explain this contemporary political phenomenon, the article argues that Roma is an identity constructed at the intersection of political and expert knowledge by various actors, such as policymakers, Romani activists, international organizations and scholars. This political-expert identity is applied to groups that are not bounded by a common language, religion, cultural practice, geographic location, occupation, physical appearance or lifestyle. The article explores how this collation of disparate populations into a notional political community builds upon a centuries-old Gypsy legacy. It scrutinizes five strands of identification practices that have contributed to the longue durée development of today's Roma as an epistemic object and policy target: police profiling of particular communities; administrative surveys; Romani activism; Roma targeted policies; quantitative scientific research. The article argues that the contemporary economic and political conditions amidst which the politicisation of Roma identity is occurring explain how the ideological and institutional construction of the ethnic frame tends toward the reinforcement of the exclusion of those categorised as Roma, thus increasing the perceived need for Roma policy initiatives. A self-sustaining cycle has been created where Roma knowledge identifies Roma problems requiring a policy response, which produces more Roma knowledge, more needs and more policy responses. Yet, there are consequences to racialising public discourse by presenting Roma as both problematic and essentially different from everyone else. Hostility towards Roma has increased in many states indicating that the expert framing of Roma groupness affects social solidarity by disconnecting and distancing Roma from their fellow citizens.
\end{abstract}

\section{Keywords}

epistemic; expert knowledge; Gypsy; identification practices; identity; inclusion policies; racialization; Roma

\section{Issue}

This article is part of the special issue "Talking about Roma: Implications for Social Inclusion", edited by Dr. Eben Friedman (Independent Consultant and Senior Non-resident Research Associate, European Centre for Minority Issues, Germany).

(C) 2015 by the authors; licensee Cogitatio (Lisbon, Portugal). This article is licensed under a Creative Commons Attribution 4.0 International License (CC BY).

\section{Introduction}

A standard narrative in mass-media, academic and policy expert accounts is that Roma are Europe's largest ethnic minority, a population of 10-12 millions scattered all over the continent (and beyond), the de- scendants of people who originated in India a thousand or more years ago. This racialised ${ }^{1}$ narrative of com-

\footnotetext{
${ }^{1}$ As discussed in the article, current representations of Roma owe much to the knowledge produced within a racial frame. Historically and now, Gypsies/Roma have been externally iden-
} 
mon kinship continues with the image of the Roma as a disadvantaged population at risk of discrimination in all spheres of life and who need special treatment for achieving life opportunities comparable with that of the non-Roma with whom they live. Efforts to overcome these disadvantages are usually referred to as inclusion or integration.

The above narrative has a large circulation in policy circles and in society at large. Since the 1990s, Roma social policies have built upon it, while less circulated stories of Roma un-grouping have failed to attract the attention of policymakers. Critical social theory tells us that ethnic, national and regional identities are social and not natural phenomena. Yet, despite the inherently transformative aspirations underpinning the politicisation of Roma identity, its proponents almost invariably present its legitimacy as a reflection of an actual Roma people, rather than acknowledging it as an identity in whose construction they are themselves playing an active part. The political imperative to claim that Roma-related initiatives reflect rather than create a Roma reality is able to draw on more than two centuries of scholarship devoted to Gypsies, and now Roma as an object of study ${ }^{2}$.

Just as political claims about Roma need to be critically examined, so does the premise from which this politics derives. This article builds on anti-essentialising perspectives that have been applied to explain Roma as a social and cultural phenomenon and it seeks to encourage the research agenda towards a constructivist position. We can see how contemporary Roma inclusion policy is not so much a break with the past as the latest form of a long-standing process of identity construction and control.

Historical context is important for several reasons. First, historians analysing the social formation of the Roma group under elite pressures and dominant discourses often do not address recent history and critical analyses usually stop before the year 1990 or earlier ${ }^{3}$. Second, political scientists ${ }^{4}$ who are critical of recent

tified and defined by surveys, police-led censuses, expert estimates and policy-related initiatives based on physical appearance and social context rather than self-identification. The political-academic consensus of Roma undercount in the census subscribes to a racialised perspective as it claims the existence of some essential Roma-ness that makes self-identification unreliable.

2 That a lack of theoretical perspective in studies about Roma renders Romani studies a marginal position in academia is signaled among others by Surdu (in press) and Tremelett (2014).

${ }^{3}$ Willems (1997) analyzes academic framing of the Gypsies as a coherent group and Klímová-Alexander (2004, 2005a, 2005b, $2006,2007,2010$ ) explores Romani activism in historical perspective. The research of Willems ends with 1945 while that of Klímová-Alexander stops before 1990.

${ }^{4}$ See for example Kovats $(2003,2013)$, Vermeersch (2005, 2006, 2012), Klímová-Alexander (2005), Simhandl (2006), developments in Roma identity politics and inclusion policies avoid examining contemporary events against historical contexts or scrutinizing non-political actors. Third, interdisciplinary criticism of Roma identity construction is rarely articulated as historians ${ }^{5}$ emphasise the influence of academic scholarship in the emergence of a public Romani identity, while political scientists concentrate more on the role of international organizations and Romani activism. Fourth, quantitative researchers - that is policy oriented researchers-most often use both a-theoretical and a-historical perspectives when explaining the Roma they are discussing ${ }^{6}$.

This article does not attempt to explain all the contentious issues and disconnections highlighted above, but notes there being different scholarly approaches to the conceptualisation of Roma across time and disciplinary fields. Recognition of the ambiguity and contestation of Roma identity provides the starting point for assessing the effects of contemporary Roma inclusion policies on the meaning of Roma and the implications for social cohesion of the identity's politicisation.

Beyond the generation of countless strategic documents at national and European levels, the socioeconomic mapping of millions of the Roma and thousands of targeted Roma programs, the reinforcement of the Roma label as an umbrella category for policy purposes should also be assessed for the effects that it produces vis-a-vis promoting a positive identity for diverse groups ostracised over time as Gypsies and currently conceptualised as Roma. In two decades, the Roma label has become institutionalised across Europe $^{7}$ and is replacing a wide variety of identities that were applied for centuries to diverse groups for de-

Popova (2015) and van Baar (2012).

5 See for example Willems (1997), Willems and Lucassen (2000), Mayall (2004).

${ }^{6}$ After 1990 quantitative research on socio-economic and antidiscrimination topics were carried out all over Europe. For example, in Romania Rughiniş (2012) analyzed 8 quantitative surveys on Roma, between 2000 and 2008, Examples of regional/European level surveys on Roma include those of the World Bank (2002), UNDP (2002, 2005), FRA and UNDP (2012). Many smaller quantitative surveys were conducted by NGOs and research institutes.

7 Efforts to replace Gypsy with Roma occurred in Romania in the interwar period (Nastasă \& Varga, 2001). Currently there is doubt as to whether the interwar Romanian Roma politics aimed at national or international recognition of Roma as a group. See for example Klímová-Alexander (2005b, p. 172) for these debates related to whether an interwar international Romani congress took place or not. Archival searches have not produced evidence that it did, though Klímová-Alexander (2005b) argues that simply the idea of organizing such a congress was important for internationalization of Romani representation. Elevating Roma to the status of a transnational group occurred in 1971 with the First Romani Congress and adoption of formal symbols of a nation such as a flag, a hymn and the proposal of a standardized language. 
marcating economic, cultural and social boundaries within European societies. While this re-branding was initiated in the political sphere, the new Roma label was swiftly adopted in other fields such as academic research ${ }^{8}$, the mass media and in administrative censuses. This newly conceptualised Roma people has many resemblances with that which has been defined as Gypsies during the last two centuries. Today's "Roma" is the contemporary inheritor of the Gypsy legacy, an identity historically fabricated by scholars, experts and bureaucrats.

To be clear, the claim we are making is not that the Roma group does not exist, quite the opposite. We assert that the group is being formed and that the driving force behind this process is competitive political interest. Acknowledging the influence of political institutions and actors (and that of political context) in the emergence of Roma as a collective political identity does not preclude the active involvement of those defined as Roma. Indeed, in democratic Europe, Roma representation and participation have flourished in parallel with Roma policy. The article confronts the question at the heart of Roma inclusion policies; are the Roma an actual group of real people that can be accurately counted and characterised, or a political concept of convenience? In terms of politics, the key distinction between whether Roma is an objectively based or a subjective identity lies in the possibility of accountability each implies. The politicisation of Roma identity is designed to change the world, but we argue that taking Roma identity at face value in policy making has negative repercussions not only for those targeted, but also obscures reflection on problems of inequality and governance in European societies that affect large numbers of people, be they Roma or not.

\section{Constructivist Perspectives on Ethnic Identity}

As the conceptualisation of Roma ethnicity has rarely been confronted by critical theories of ethnicity, we offer here some approaches that could inform such a research agenda. We begin with Max Weber's influential view of ethnicity which sees ethnic groups as socially constructed and ethnicity as contextual, situational, performative and fluid. Constructivists reject the assumption of quantitative studies that claim ethnicity is objective, stable and independent of socio-political and economic contexts.

Critiques of cultural essentialism go beyond the concept of ethnicity and point to the intermingling of cultures in processes such as of colonization and globalization, as well as to cultural hybridity, migration and intermarriage (Bhabha, 1994; Burke, 2013). Other per-

\footnotetext{
8 Some historians and anthropologists still use the name of Gypsies (usually interchangeable with that of Roma) in order to reflect self-ascription and for historical accuracy.
}

spectives refer to the fictive character of ethnicity, understood as fabrication in the context of nation-state formation (Balibar, 1991) or to the anthropological description of foreign cultures as indirect accounts of a third order (Geertz, 1973). From a postcolonial perspective, Said (1978) approaches ethnic identity as a product of Western scholarly, literary and political traditions of exoticizing the Other, while Spivak (1987) addresses the instrumentalization of the subaltern voice and the pursuit of self-interest by spokespersons assuming the role of representing oppressed groups.

The spokespersons' role in the formation of ethnic groups is crucial for a social constructivist perspective. Political entrepreneurs, spokespersons and mediators are considered key actors for ethnicity formation, their contribution expressed in elevating minor cultural differences to an essential status (Balibar, 1991; Banton, 2007; Barth, 1969; Bourdieu, 1991; Brubaker, 2004; Jenkins, 1997; Weber, 1922/1978). Insight into categorization and grouping for academic endeavours also comes from science and technology studies. Scholars (Bourdieu, 1991; Callon, 1986; Latour, 2005) have argued that scientists and experts assume the role of spokespersons for groups that they describe through their research and that this scientific enterprise calls the group into being allowing spokespersons to transform in actors. Bourdieu and Waquant $(1999,2001)$ consider that ethnicity is used as a euphemism for race, being a concept globally adopted (including in Europe ${ }^{9}$ ) from the US context by scholars, semi-scholars and politicians with the effect of shifting debates around social and economic inequality towards one of ethnic difference. Suggestions to supersede essentialism point to an understanding of ethnic frames as a result of stereotypes, social categorizations, and cognitive schemes for interpreting the world (Brubaker, Loveman, \& Stamatov, 2004).

The article discusses processes of social categorization that have contributed to the evolution of Roma identity, emphasising the role of political actors, institutions, scholars and Romani leaders and activists in the emergence of what we call the Roma political phenomenon. We argue that Roma is a dynamic political identity constructed mainly from above and from outside by political and expert communities and thereafter applied or adopted by people subjected to public labelling and policy interventions. Furthermore, this social

\footnotetext{
${ }^{9}$ While we agree with Bourdieu and Waquant's $(1999,2001)$ thesis, nevertheless we believe it doesn't apply indiscriminately to the whole of Europe. Western European countries tend not to officially sanction ethnicity (two big countries such as France and Germany do not record officially ethnic identity in censuses for example) while countries in CEE account for ethnocultural groups in official records. See for example Simon (2007) for an account of European countries that collect "ethnic data" and those that do not. In this regard Western Europe is closer to a model of civic nation while CEE countries adopt rather ethnic forms of nationalism.
} 
categorization produces effects on those assigned to a category in a looping effect (Hacking, 1986, 1995) by which external ascription becomes self-ascription in a normative and prescriptive sense, setting up and limiting the potential for action of those categorised by experts. Though Roma policy routinely seeks inclusion, the newly institutionalised Roma label may strengthen the rejection of Roma by others and self-ascribing to the label may also entail the acceptance of expectations that limit aspirations and opportunities.

\section{Scholarly Contributions to the Gypsy Legacy}

The Gypsy Legacy includes the long-standing conceptualization by scholars, authorities, activists and experts of the Gypsies as a distinct ethnic group and transnational diaspora which informs current discursive and policy approaches towards Roma. For a critical analysis of this legacy we draw on what Stewart (2013) refers to as the socio-historical approach to Romani studies. Major contributions are those of Okely (1983), Lucassen (1991), Willems (1997), Lucassen, Willems and Cottaar (1998), and Mayall (2004). Willems' (1997) work is particularly important as it makes a thorough analysis of influential scholarly figures (Grellmann, Borrow and Ritter) and of their works that have shaped the conceptualization of the group that is the focus of Gypsy studies (more recently, Romani studies). Okely's (1983) book is important for explaining two important aspects of the Gypsy categorization process: historiographies of the Roma should be read with caution given the particular interest of dominant non-Roma elites who wrote them; an Indian origin assigned to all Roma (as with the Egyptian origin previously assigned to Gypsies) is merely a means of collectively exoticizing groups of people of diverse origins who failed to become absorbed into the salarial system with the transition from feudalism to capitalism.

One conclusion derived from the socio-historical approach to which our article subscribes is that Gypsies (and later Roma) have been collated and transformed from an administrative category to an ethnic group by singularization, minoritization, exoticization and stigmatization through the classification work of policemen, state authorities, church representatives, writers, experts and scientists. Anthropologists doing participative research in Gypsy communities (Stewart (1997) in Hungary, Gay y Blasco (2001) in Spain, and Okely (1983) in the UK) have noted that their subjects consider the issue of origins and ancestry highly irrelevant. Yet, a dominant theme in Gypsy/Romani studies (that has acquired a new political salience) has been the claim that the Romani people come from India, even when this assertion is contradicted by the selfnarratives of people assimilated by scholars and policymakers into the Roma group ${ }^{10}$.

10 This is the case for example of Egyptians in countries of for-
A bibliometric analysis of Roma-related studies published since 1990 (Surdu, in press) shows that policy research by international organizations and genetic studies of Roma have scored highly in academic influence and recorded the largest number of citations ${ }^{11}$. Among policy studies, most frequently cited are World Bank and Council of Europe (CoE) publications. Studies by the UNDP have also proved influential in portraying the Roma group as a unitary whole for policy purposes. These policy discourses combine the vagueness of the concept of Roma with the political incentive to address objective problems of poverty and exclusion to confusingly portray Roma both as an ethnic minority and a disadvantaged group ${ }^{12}$.

While the strategy of the policy-maker is to mobilise an ethnic perspective to target disadvantage, this presentation of Roma cannot but contribute to a perception of cultural characteristics of the group itself being responsible for its members' poverty and social exclusion. As Surdu (in press) argues, the World Bank's most widely read publications $(2000,2002,2005)$ have constructed a Roma profile that inevitably cites Roma culture as contributing to poverty, low educational participation, dire living conditions in Roma settlements and the avoidance of public health care systems. The public image of Roma as a welfare dependent group was also shaped by a UNDP (2002) study which offered representations of collective criminality and deviance (Acton, 2006; Surdu, in press). Policy texts not only describe highly stigmatic images of the Roma, but the message is reinforced by the use of photographs representing how needy Roma really are (Surdu, in press).

Of particular importance for the rise of Roma as a political identity have been the interests of European political institutions. Presented as a pan-European ethnic minority, Roma can symbolise the need for European governance. The $\mathrm{CoE}$ was an early champion declaring "the Gypsies" a "true European minority" (Kovats, 2001). The CoE has been promoting European Roma governance since 1995 and and its estimates of the (probable) size of national Roma populations, and hence that of Europe as a whole, are those often cited in international (and even national) policy debates despite being far higher than what people say about themselves and the opacity of the method used in their calculation ${ }^{13}$. The preference for a large Roma number reflects a need to justify institutional involvement. The

mer Yugoslavia, Rudari in Bulgaria and Romania, Boyash in Croatia and Hungary. As our aim is not to decide among narratives of origins but to point to the political preference for a simplistic racial narrative.

${ }^{11}$ Recorded with Google Scholar search engine.

12 See also Popova (2015) for this dual positioning as an impediment for Roma inclusion policies.

13 See for example Liègeois (1986), where estimates of Roma populations' size are provided without citing sources. 
CoE first published estimates of the number of Roma in Europe in 1994 (Liègeois, 1994) and for more than a decade these figures were continuously reproduced not only by the CoE but also in most policy studies and mass media ${ }^{14}$. A 2007 CoE publication (Liègeois, 2007) gave the same number of Roma for countries such as Bulgaria, Hungary, Romania and Spain. It is unlikely that if these figures bore a relationship to an actual population they would register neither increase nor decrease over more than a decade. The authority underpinning the most widely quoted Roma population estimates, the most basic numbers of the Roma political discourse, is political rather than scientific.

The repetition of Roma population estimates is a technique of truth production supported by other expert estimates produced by think thanks, academics and Romani NGOs, and reproduced by international organizations, that has established the conventional wisdom that census enumeration of Roma significantly under-records their "real number". Interestingly, the presumption that determining who is Roma on the basis of self-identification undercounts how many there really are appears frequently in expert studies as far back as the interwar period allowing Roma experts to assume the role of identifying the "true number" of Gypsies/Roma in a country or for Europe as a whole.

This assumption of a Roma undercount in the census credits a racialised conception of the group according to which what counts as Roma is not self-ascription or objective characteristic, but public perception and expert assertions that unify the Roma through a belief in common kinship. The question of the validity of numbers for a population which self ascribes to Roma identity and one composed of those whom others label as Roma is less a methodological problem (as obviously both such populations exist), more an ethical one. One might think it would be better to count as Roma those who say they are Roma rather than those given a stigmatising label which has already proved so calamitous to people similarly labelled in the past.

Given high rates of discrimination, there may well be people who fear identifying as Roma, but this number has not been tested or quantified. For essentialists Roma are Roma, but understood as a social construction we can see that the issue is actually how people relate to Roma identity. The politicisation of Roma identity is a process of making Roma. As Simonovits and Kezdi (2013) argue, self-identification as Roma is significantly influenced by economic position. In addition, the fact that those registering as Roma has increased over time (including as a result of census campaigns by governments and NGOs explicitly encouraging people to choose Roma ethnicity) indi-

${ }^{14}$ See Surdu (in press) for an in-depth analysis of the size of Roma population as a discursive frame in academic and policy discourse. cates that the anonymous and confidential selfdeclaration of being Roma is not significantly impaired in the census. In short, we believe that for census purposes declaring oneself as Roma or not is largely a matter of agency and dependent on status position.

Since the 1990s, much detail has been added to the political image of Roma through surveys claiming to be representative, but which are actually based on biased samples (Surdu, in press). As several scholars suggest (Prieto-Flores, Puigvert, \& Santa Kruz 2012; Rughiniş, 2011; Surdu, in press), quantitative research on Roma almost exclusively samples among the poorest individuals and communities and tends to avoid better off subjects. This reinforces both a pathetic image of Roma and justifies policy intervention. Scholarship's contribution to stigmatising Roma as a marginal group has been added to by the frequently cited policy oriented research produced by NGOs (Marushiakova \& Popov, 2011)

Quantitative Roma studies use ethnicity to explain a broad range of phenomena, from poverty to low school graduation rates, ignoring that social status influences how people see themselves and self-ascribe under ethnic labels. If samples in earlier surveys were based almost exclusively on external identification, more recent studies introduce community level heteroidentification as a principle, even if in selecting "Roma communities" they rely on information provided by NGOs, other experts or public officials. That expert categorizations, be it done by field operators or other Roma experts, do not coincide with self-ascription was shown by Ladányi and Szelényi (2001) in Bulgaria, Hungary and Romania. Yet, this magisterial empirical demonstration of the ambiguity of Roma identity and the inconsistencies of its measurement seems to have made little impression on policy researchers.

Though it would be wholly erroneous to imagine that there is a scholarly consensus that Roma identity represents a racial diaspora of Indian origin, this thesis has political utility in that it provides a reason for bringing under one conceptual umbrella a vast number of far flung communities with diverse cultures and contexts (the other main justification is that all Roma suffer a universal prejudice and discrimination, however this has the problem of meaning that Roma are defined by those who hate them). Beyond policy studies, publications about the genetics of Roma have frequently been cited in scholarly productions in recent decades. Since the first sero-anthropological study ${ }^{15}$ in 1921, Gypsies (and now Roma) have been constructed as a genetic object by specialists operating in different regimes of identity politics (Lipphardt \& Surdu, 2014). Genetic studies since 1990 (population or medical genetics) build on narratives imported from social sciences such as Roma endogamy, Indian origin and popula-

15 Verzár and Weszeczky (1921). 
tion size. These narratives are, in turn, strengthened by revived confidence in the objectivity of genetic science $^{16}$. Although the data produced may equally sustain alternative interpretations, through small, haphazard samples, contemporary genetic studies have presented findings for Roma in Europe that appear to provide conclusive scientific support to public perceptions of Roma foreignness and genetic isolation. The quest to prove Roma racial distinctiveness has inspired interdisciplinary collaboration between genetic scholarship, humanities and the social sciences to produce evidence for the reification and stigmatization of those included in the Roma group (Lipphardt \& Surdu, 2014).

\section{Roma in Censuses}

National censuses also contribute to the homogenisation and spread of Roma group identity. The census is an administrative tool and not an objective method for recording ethnicity and race, but census categorization can be instrumental in the formation ethnic and racial groups (Aspinal, 2009; Bowker \& Star, 2002; Goldscheider, 2002; Kertzer \& Arel, 2002; Labbé, 2009; Nobles, 2002; Robbin, 2000; Surdu, in press). Historically, the census appears decisive in Gypsy/Roma group formation for the purpose of governance. Two examples are sufficient to demonstrate this point, one from Romania and the other from Hungary.

Before examining the construction of the Roma category in the contemporary census, we should consider the historical transition of Gypsy from a regulatory and fiscal category into an ethnic one. In the "Romanian" principalities of Moldova and Wallachia, Gypsies were slaves (robi) for almost five centuries, the fragmentary historical record of which has been the subject of scholarly analyses. Gypsy was a distinct servile legal category closer to classical than plantation slavery, and differing from contemporary serfdom in not being necessarily tied to agricultural production. The legal proscription of marriage between Gypsies and non-Gypsies was to regulate property, not ethnicity.

Those who theorise common origins as the essential characteristic of Roma prefer to see a happy coincidence in the arrival and enslavement of immigrants with recent origins in India, rather than considering that centuries of social and economic marginalisation might create communities that, though differing from each other, share a low social position and that this entrenched low social status could be adapted to racial explanations of difference as such ideas developed in European culture from the eighteenth-century. Applying to Gypsies a racial perspective derived for the later Atlantic slave trade may be politically attractive, but is not historical.

${ }^{16}$ See Surdu (in press) for a case study on genetic studies on Roma after 1990.
The categorization of people as Gypsy slaves was a dynamic process influenced in several ways: landowners were motivated to declare their workers as Gypsies to reduce tax, pauperised peasants could sell themselves as Gypsies, the non-Gypsy spouse and children of a Gypsy became the property of the owner, strangers, prisoners or the masterless, could be assimilated into the Gypsy category as a means of controlling their labour power. Conversely, people could leave the category (and hence identity), Gypsies could buy their freedom or find the protection of another master ${ }^{17}$. One former Gypsy even became a Prince. The late Roma theorist and activist Nicolae Gheorghe recognised that during the medieval period the term Gypsy was a label reflecting a social and not an ethnic status (Gheorghe, 1997, 2013). His view has been vindicated by a recent study of archive documents about nineteenth-century Gypsy slavery, which found no reference to Gypsies being seen as an ethnic group (Venera Achim \& Tomi, 2010). Furthermore, Venera Achim (2005) has shown that in the first systematic administrative data collections (catagrafii) made during nineteenth-century, Gypsies were not considered a cohesive ethnos but a fiscal and social category. The first census in Romania to record Gypsy as an ethnicity took place in $1930^{18}$ and this practice continued into the communist and postcommunist periods.

Despite the principle of ethnic self-ascription, in the Romanian 2011 census, a total of 19 different identities $^{19}$ were administratively subsumed under the label of Roma, illustrating how, despite the firm belief in undercount, even the census inflates the number of those who actually choose to call themselves Roma. Responding to the question about ethnicity was optional and more than 1.2 million people did not record one. Nevertheless, the theory of Roma undercount enabled the mainstream media and sociologists to attribute this high number of undeclared ethnicity to Roma who allegedly wanted to hide what they really were. The firm conviction that there must 100,000 s of Roma hiding their true identity (thus implying a certain dishonesty) appeared unshaken by the fact that the census also recorded a higher number of Roma than its predecessor (not least as a result of the post-coding operation explained above as well as campaigns conducted by Romani NGOs which claimed that self-identifying as such could increase resources going to Roma) .

The first systematic ${ }^{20}$ census of Gypsies in Hungary

\footnotetext{
${ }^{17}$ See for example Viorel Achim (2004) and Giurescu (1943).

18 For a discussion on interwar censuses' recording a Gypsy ethnicity in their political and academic context see Surdu (in press).

19 Many of them designating "Roma sub-groups" in anthropological parlance.

${ }^{20}$ For the whole of imperial Hungary except for the city of Budapest.
} 
was carried out by the Royal Hungarian Statistical Office in 1893 and was based on external identificationrecording as Gypsies those considered so by their external environment (Havas, 2002). Many scholars consider this a scientific census of the late nineteenthcentury Gypsy population though in fact it was commissioned by the Ministry of Interior (Kemény, 2000; Willems, 1997) and carried out by the Royal Society of Demography. As with other scholars in Roma-related research who also undertook political functions, the lead researcher of 1893 census (Arnold Hermann) was both the president of the Statistical Office ${ }^{21}$ and chief counsellor for the Ministry of Interior. Since the patron of this special Gypsy census was the police and the executors were professional demographers, it is likely that a collaboration and an exchange of opinions between these two types of Gypsy expertise took place. Such collaboration between police and academics is even more plausible given that the reason for the census was to assess the problem of vagrancy following waves of immigration from the east ${ }^{22}$. The same definition of a Gypsy (s/he others consider a Gypsy) was also applied in national Gypsy surveys carried out under the aegis of the Hungarian Academy of Sciences from 1971 into the new millennium (Havas, 2002).

\section{Police Profiling}

Police work has one of the oldest research traditions of employing external identification for the conceptualization of Gypsy populations ${ }^{23}$. According to Lucassen (1998), the professionalization of the police and the emergence of police journals in Germany in the eighteenth-century led to the categorization of diverse and unrelated individuals and groups of people under the label Gypsy (Zigeuner), with priority given to those with an itinerant lifestyle and without fixed residency. Though mainstream criminologists rejected the theory of the natural born criminal and acknowledged the crucial role played by environment in criminal offences ${ }^{24}$, from the end of nineteenth-century a biologically deterministic theory of criminal behaviour inspired the science of criminology ${ }^{25}$ and further increased police interest in Gypsies as a population to be identified and controlled.

In the first half of the twentieth-century, the uni-

\footnotetext{
${ }^{21}$ See Kemény (2000).

22 Yet the census categorized a merely $3.3 \%$ of those surveyed as vagrant (Havas, 2002)

${ }^{23}$ For a more detailed discussion on similarities and departures in police and policy analysis research practices see Surdu (in press).

${ }^{24}$ See Surdu (in press) for a brief discussion of critical reception of Lombrosian theory in its historical context in France, Germany and Romania.

${ }^{25}$ For an analysis of Cesare Lombroso references to Gypsies in his work see for example Widmann (2007).
}

form perception of the Gypsy group as a dangerous class was further developed by collaboration between police, academics and Nazi authorities leading to a definition of Gypsies used for persecution and extermination ${ }^{26}$.

This police work on Gypsy identification is important not only for its contribution to repressive policy measures, but also because it stimulated the external identification of Gypsies in other fields, such as the administrative census and academic scholarship. The importance for the police of creating the Gypsy as a target group is likely also to have led to the codification of Gypsies as a distinct identity in official censuses as the first special censuses carried out or commissioned by police preceded the administrative censuses that record a Gypsy ethnicity ${ }^{27}$. Gypsy-only censuses were carried out by the police in other countries and under different political regimes, including national socialism and communism.

In France, special censuses of nomads and Gypsies were undertaken by the police in 1895 and anticipated the introduction of special identity papers for Gypsies - the so called carnet anthropometrique de nomad which, when introduced, applied to a large number of French citizens who had lost their jobs during the finde-siècle economic crisis and who were incentivised to apply for one as possession would avoid being arrested for vagrancy ${ }^{28}$. These Gypsy IDs were required by law in 1912 and kept in use until 1969. Even in today's France special papers for Gypsies are used as a mean of identity verification by the police (Kaluszynski, 2001) ${ }^{29}$. Alongside enumeration in special censuses in France, anthropometric identification known as bertillonage (involving forensic photography) became a technique transferred from the identification of delinquents and suspects to the identification of Gypsies and nomads, who were seen as a threat to national security ${ }^{30}$.

Inspired by French anti-nomadic legislation, in 1927 Czechoslovakia adopted the identification of Gypsies by special IDs. Special censuses of Gypsies were also conducted by the police in Romania in the interwar period, identifying Gypsies later subject to deportation in

${ }^{26}$ The empirical failure of racial scientists to demonstrate a distinct Gypsy genetic heritage was no obstacle to Nazi theorists as Gypsies could be targeted for persecution on the grounds that the mixture of Gypsy and non-Gypsy blood explained their deviancy. See for example Müller-Hill (1988), Willems (1997) and Lucassen (1998).

${ }^{27}$ In Czehoslovakia for example the first census having category Gypsy for nationality and language was in 1921 (KlímováAlexander, 2005 b). In Romania the first census recording Gypsy ethnicity and language was carried on in 1930.

${ }^{28}$ See About (2012, pp. 109-110).

${ }^{29}$ For a history of Gypsies identification and surveillance by the police in France since nineteenth-century see also About (2012).

${ }^{30}$ Kaluszynski (2001), Filhol (2007). 
Transnistria, which resulted in thousands of deaths ${ }^{31}$. Gypsy-only special censuses by the police or other forms of data gathering were undertaken in Bulgaria and in other communist countries ${ }^{32}$, the population estimates of which differed widely from those produced by national censuses (Liègeois, 1994; UNDP, 2002; World Bank, 2000). While communist approaches were notably inconsistent, continued interest in the quantification of Gypsies points to the ambivalent rhetoric and practice of the period. In the postcommunist period, these police derived population estimates have been preferred by policymakers over census numbers (notably the figure used for Romania-the highest for any European country-which originated in a report by the Securitate of the Ceauşescu regime). The surveillance of Roma by the police and their conceptualization as a suspect population continues today. In 2010 the French press reported the existence of an interministerial database used by the Gendarmerie and built since 1997 for the purpose of monitoring Gypsies, Roma and Travellers for criminality ${ }^{33}$. Another recent example is that of Sweden where a police database held information on 4029 individuals including children, elders and people without any previous convictions based solely on their ascribed group membership ${ }^{34}$.

\section{The Politicization of Roma: Romani Activism and International Organizations}

We consider that the history of Roma activism can be seen in terms of the construction of a political community classed as Roma, which can be the subject of both public representation and targeted policy actions. Following Klímová-Alexander's series (2004, 2005b, 2006, 2007, 2010) of carefully documented accounts on Romani representation from the Middle Ages up to 1971, we argue that in most cases Gypsy leadership and representation have been instigated by extracommunal actors with the purpose of administrating and managing a broad range of populations that were not otherwise included in conventional social control mechanisms. As Klímová-Alexander argues, from as early as the fifteenth-century leadership positions over a Gypsy group, be they held by a Gypsy or otherwise,

\footnotetext{
31 Archive documents about the categorization of Gypsies and the organization of this census can be found (in Romanian language) in collection edited by Nastasă and Varga (2001).

32 The practice of external identification of Gypsies was also employed in social research in communist period an example being that of Hungary which in a 1971 survey used heteroidentification for mapping Gypsy population of the country. After 1990 this practice stirred a heated debate between advocates of external categorization of Roma and those asking for retaining only self-ascription in sociological research.

${ }^{33}$ About (2012).

${ }^{34}$ See Nordenstam and Ringstrom's (2013) article from 23 September 2013, Police database of Roma stirs outrage in Sweden.
}

were often assigned by states in order to help with the collection of taxes and to maintain social control. The unification of groups and families characterised as Gypsy under the authority of a leader was primarily a matter of surveillance and management ${ }^{35}$. Gypsies were united from among dispersed and unrelated families into larger units around a lord, location or profession for the purpose of more efficient tax collection and labour control. Leaders enjoyed privileges such as tax exemption for themselves and the right to mete out punishments. The more cooperative leaders were, the more likely they were to be rewarded and supported by their superiors to maintain their power (Klímová-Alexander, 2010).

At face value, the rise of Roma political consciousness and self-organisation (particularly since 1990) appears a fundamental break with the long Gypsy Legacy of exclusion from formal political life. However, it can also be seen as a continuation (in modern democratic form) of this age-old necessity of mainstream authorities requiring an intermediary through which to exercise control over "hard to reach" communities. Contemporary Roma leaders benefit from the huge increase in resources (primarily derived from the growing number of Roma projects) and status as recognised representatives (required to legitimate institutional intervention by the state). This creates a shared interest between ambitious Roma and mainstream institutions to construct a Roma "people" and to ethnicise social policy (Klímová-Alexander, 2005a; Kovats, 2001, 2013; Simhandl, 2006; Vermeersch, 2005).

If a central (though not universal) idea of Roma activism is to present Roma as a transnational nation in order to subvert nation-state governance and ideology, the last twenty years show it as often having the opposite effect and contributing to the revival of domestic nationalisms. Roma nationalism itself makes conventional demands for the political representation of an ethno-cultural group. The early Romani movement in interwar Romania was inspired by the Romanian nationalism of the time and was supported by two of its main institutional proponents, the Orthodox church and parties of extreme right (see for example Matei, 2010, 2011). An influential Polish Roma family lobbied the League of Nations and Mussolini for a Roma homeland in Africa. Apologists have argued that the links of these Roma leaders with the political establishment should be seen as merely an instrumental use of opportunities offered by the political context ${ }^{36}$, but that does not add to our understanding as politics is always the art of the possible.

\footnotetext{
${ }^{35}$ As Klímová-Alexander argues, historically some of the leaders cooperated not merely with fiscal authorities but also with the secret police. Currently there are no sources to document whether cooperation of assigned leaders of Roma with secret police prolonged in communist countries after 1945.

${ }^{36}$ See details on this debate in Klímová-Alexander (2007).
} 
Since the turn of the millennium, transnational Roma activists have tried to develop the concept of a Roma nation without a state (Declaration of a Nation, IRU 2000 cited in Sobotka, 2001). This at least recognises that any attempt to corral Europe's Roma into a single territory would entail massive human rights abuses, but it ignores that the authority to effectively represent can only arise with legal and fiscal power over (and preferably a mandate from) those who are claimed to be represented. All of these pre-conditions are entirely illusory. Nevertheless, the persistence of the apparently perverse aspiration to deprive Roma people of their status and rights as national citizens demonstrates the importance of empty symbolism in the Roma political discourse.

\section{Policy Making and the Presentation of Roma as an Oppositional Identity}

The legacy of academic scholarship, police identification, census design and Romani activism has become incorporated into Roma-related policy research and policy making. This knowledge transfer is reflected in the three main assumptions of most policy studies and documents: first, the size of the Roma group is considered to be significantly larger than that recorded in the census; second, all Roma are seen as members of a transnational ethnic minority whose ancestors came from India to Europe centuries ago; third, Roma are seen as a closed ethnic community little influenced by global tendencies of cultural hybridity. Policymakers and often policy researchers project Roma as an oppositional identity to those of the mainstream state and society-ideologically reflecting the qualitative presentation of Roma as distinctly poor and/or excluded.

Since the end of the Cold War, the knowledge transfer between scholarship, activism and policy has benefited from the process of European integration to propose Roma as a transnational minority across Europe in order to encourage European political institutions to engage with and develop Roma as a unique political object. Europeanisation provides an extra dimension to Roma exclusion by moving responsibility for overcoming barriers to social mobility away from national governments and towards the European level and from national politicians to civil society actors such as NGOs (Agarin, 2014; Rövid, 2011; Sigona \& Veermersch, 2012; van Baar, 2012).

As Vermeersch (2012) argues, the elevation of Roma issues to the European level has also given rise to a politics of reinterpretation that reinforces exclusive nationalist rhetoric, fuels an anti-Roma agenda, confuses lines of political accountability (between national authorities, European institutions and non-state actors) and favours a perspective of blaming the victim. Ironically, the aspiration to collate Roma into one group to justify transnational European governance also de-
Europeanizes Roma as many policy documents assert their Indian origins. This exoticisation is further supported by the aspiration to apply a racial civil rights paradigm to Roma. In this way the narratives and myths of Roma origins circulate in policy circles strengthening the otherness of Roma while affirming their alien European-ness. The greatest casualty of this way of thinking is the downgrading of national citizenship and consequently of all rights and entitlements deriving from such a status.

The politicisation of Roma identity is not only a state-led initiative, but is also promoted by the private sector. Communicative practices of NGOs for advocacy purposes build the image of Roma as needy and threatening, which has contributed to keeping antiRoma sentiments high (Gheorghe, 2013; Schneeweis, 2015; Timmer, 2010). Scholars acknowledge that a major shortcoming of the anti-discrimination discourse adopted by NGOs and international organizations is to accentuate divisions between Roma and non-Roma which are often presented as oppositional identities.

Critical analyses argue that anti-discrimination initiatives fail to challenge the structural causes of the socio-economic decline of many of those labelled as Roma from being a relatively well adapted group in socialist economies to a pauperised one in current neoliberal regimes of CEE (Kovats, 2003; Sigona \& Trehan, 2009; Surdu, in press; Templer, 2006). Moreover, when addressing "Roma" discrimination, the structural causes of disadvantage and exclusion (such a low labour demand, weak institutions, lack of accountability) and the functionality these create for discriminatory practises are largely ignored while the ethnic discrimination frame is enforced. This narrative that Roma people are primarily the victims of their neighbours' ignorance or hatred (which enlightened institutions can but try and combat) seems most likely to undermine social solidarity, whereas an agenda of systemic discrimination would attract larger constituencies, not least since the economic crisis has brought with it increased pauperization in Western and Eastern Europe alike.

Placing all Roma into an anti-discrimination paradigm as a way of fostering their inclusion seems not to be an effective method for solving individual cases of abuse and mistreatment but has led to largely cosmetic changes to particular exclusionary mechanisms. Though repeatedly identified as a high priority, institutional anti-discrimination initiatives have been too limited to create a critical mass, producing only symbolic victories that leave unchanged the root causes of unequal treatment. Roma rights advocacy has produced a backlash in states such as Hungary and Bulgaria where it is presented as an example of a foreign (inspired) liberal elite's rejection of national culture and societies, allowing racist prejudices to be mobilised to undermine the value of human rights in general. The very complacency of symbolically condemning hostility towards 
Roma while failing to address its causes can be seen as a form of racism.

If the human rights discourse about Roma can be criticised, the economic approach pursued by policymakers is even more amenable to the production of negative outcomes. As Friedman (2014) argues, the tendency to put "Roma issues" under an economic rationale has come to override the human rights perspective. This is not surprising as from the first attempts at framing Gypsies as a population, economic arguments have played a crucial role in the group's definition. The founding father of Gypsology in eighteenth-century, the German scholar Heinrich Moritz Gottlieb Grellmann, used economic arguments to claim the coherence of the group, which he saw as a labour resource the improvement of which would be of benefit to society. Van Baar (2012) notes that current neoliberal social policies, advocated and facilitated by international organizations such as the World Bank, European Union and UN agencies, have given rise to a new form of governmentality for the Roma group. With the triumph of the neoliberal social and economic agenda, Roma were proposed by the World Bank as an opportunity to test employment activation schemes, which amounted to the exploitation of cheap labour, degrading and socially devalued jobs with dehumanising consequences for the individuals subjected to them while also publicly reinforcing a stigmatic image for the group as a whole (van Baar, 2012).

Roma social policy intervention is a growing sector, though there is no accepted figure for how large it has become with estimates rarely published. The largest of these claims up to three-quarters of a billion euros (OSCE-ODHIR, 2013) however (illustrating the fundamental lack of accountability inherent in the artificiality of Roma as a policy object), this estimate is derived from an unscientific aggregation of incompatible data. More realistically, a database ${ }^{37}$ compiled by the Decade of Roma Inclusion of explicit Roma projects in 12 states since 2005 years adds up to around 200 million euro (Bojadjieva \& Kushen, 2014). The adoption by the EU of its Framework for National Roma Integration Strategies means that the number of (and therefore spend on) Roma projects and programmes will continue to rise until at least 2020. While the Framework undoubtedly extends the politicisation of Roma identity, it at least attempts to draw a line in terms of governance by defining Roma inclusion as the responsibility of Member States i.e. asserting the rights and status as citizens of those labelled as Roma. Unfortunately, this creates an in-built hostage to fortune in that if Member States don't comply, the EU is left either climbing down or taking on even more political responsibility through strengthening European Roma governance!

37 The database can been searched at http://www. romadecade.org/about-the-decade-decade-good-practices

\section{Conclusions}

While the original idea of replacing the label of Gypsy with that of Roma was to escape historically accumulated negative connotations, the effect of the combined politicisation and Europeanisation of Roma identity since 1990 has been to institutionalise, as Roma, the stereotypical legacy of the Gypsy label. The failure of the political project to create Roma as a new identity is due to the fact that the ultimately economic failure to create demand that incentivises investment in higher need and less productive citizens has led to Roma being identified as a target group for inclusion. The ineffectiveness of Roma policy initiatives (due to lack of accountability) results in Roma being publicly presented as both different and unequal, accentuating the stigmatization of the group. The paradox of the Roma political project and its inclusion policies is that the more policymakers peddle inadequate interventions that target Roma as a particular, distinct and identifiable group, the more they build up and cut off this group from normal politics and societal relationships. Targeted policies on Roma have created a growth industry where 'need' is practically infinite and there is plenty of scope for new expert-government networks, but where failure is rarely sanctioned. Rather than improving lives and contributing to social cohesion, this separate system of expert governance is able to disregard (and even benefit from) the danger of further distancing Roma people from their neighbours and fellow citizens.

A crucial source of legitimacy for Roma expert governance is derived from the participation of (selfdeclared) Roma people, especially the endorsement of Roma representatives. Consequently, international policy documents routinely refer to the need to involve Roma in policy processes. This adds further political risks, some of which have already materialised. The first one is to establish token Roma participation with only a few Roma activists and organisations operating at a high level in national or international institutions, but who lack the power to affect strategic political decisions, only to ratify them. History lessons show that state authorities and international players will prefer weak leadership in order to ensure cooperation within their dominant paradigm. The instrumentality of representation means that lack of accountability remains a defining characteristic of Roma representation as the diffusion, diversity and subjectivity inherent in Roma political identity means it is hard to believe that democratic structures of Roma participation could be put in place at the European level. Merely replacing non-Roma with Roma in leadership positions in existing policy processes has little chance to substantively change the current situation insofar as the causes of poverty and exclusion are structural and not related to the personal qualities (or 
lack of them) of those in management positions.

Seen in this light, the advancement of Roma in leadership positions reduces pressure to tackle institutional mechanisms of exclusion and moves responsibility for the eventual failure of inclusion policies onto the Roma themselves. A good example of this process is given by a consultation document issued by the CoE in late 2014 on a proposal to establish a European Roma Institute (ERI) to promote Roma culture and identity. The rationale argued that the ERI was needed to address the problem of low Roma self-esteem (due to prejudice and discrimination). This newly invented Roma problem was considered important because if Roma self-esteem can't be raised, Roma cannot participate effectively. Furthermore, participation itself was defined as a pre-condition for making the right policy decisions. In its struggle against prejudice and discrimination, the Council of Europe considers that Roma people (uniquely among all citizens) cannot expect to be served better by public authorities and organisations until they have a bit more self-respect (CoE, 2014)!

As a collective entity, the notional Roma people and political community serves the interests of institutions and organizations that seek to govern the entity that they themselves have created through programs, projects and policies developed in parallel to existing structures of governance. The universally disappointing results of the OCSE Roma Action Plan, Decade of Roma Inclusion, EU Roma Framework, as well as of numerous national and non-governmental initiatives show that separate Roma policy has not improved outcomes for those under the Roma policy umbrella. In accordance with the European Commission's 10 Common Basic Principles on Roma inclusion, we contend that better outcomes can be achieved by strengthening civic entitlements and promoting an equalities culture. Without addressing the structural problems that cause poverty and exclusion, racism and discrimination, the politicisation of Roma identity must inevitably provoke political crises.

\section{Acknowledgements}

The authors thank the Decade of Roma Inclusion for providing access to its Roma projects database. Mihai Surdu was supported by a grant from Open Society Foundations (2012-2014) and by a postdoctoral fellowship at the Max Planck Institute for the History of Science, Berlin (2014). He is grateful to both institutions for the financial support for the research informing this article. Mihai Surdu also thanks Veronika Lipphardt for her encouragements, exchange of ideas, continuous support and guidance in opening new fields of inquiry. Both authors assume responsibility for the text of the article and their views represent their individual positions.

\section{Conflict of Interests}

The authors declare no conflict of interests.

\section{References}

About, I. (2012). Underclass Gypsies: an historical approach on categorization and exclusion in France in the nineteenth and twentieth centuries. In M. Stewart (Ed.), the gypsy "menace": Populism and the new anti-gypsy politics (pp.95-117). London: C. Hurst \& Co.

Achim, V. [Venera]. (2005). Statistica ţiganilor în principatele române în perioada 1830-1860. Revista istorică, XVI(3-4), 97-122.

Achim, V. [Venera], \& Tomi, R. (Eds.). (2010). Documente de arhivă privind robia ţiganilor: epoca dezrobirii. Bucureşti: Editura Academiei Române.

Achim, V. [Viorel]. (2004). The Roma in Romanian history. Budapest: Central University Press.

Acton, T. (2006). Romani politics, scholarship, and the discourse of nation-building. In A. Marsh \& E. Strand (Eds.), Gypsies and the problem of identities. Contextual, constructed and contested (pp.27-37). Istanbul: Swedish Research Institute.

Agarin, T. (2014). Travelling without moving? Limits of European governance for Romani inclusion. Ethnicities, 14(6), 737-755.

Aspinal, J. P. (2009). The future of ethnicity classifications. Journal of Ethnic and Migration Studies, 35(9), 1417-1435.

Balibar, É. (1991). The nation form: History and ideology. In É. Balibar \& I. M. Wallerstein (Eds.), Race, nation, class: Ambiguous identities (pp.86-107). London: Verso.

Banton, M. (2007). Max Weber on "ethnic communities": A critique. Nations and Nationalism, 13(1), 19-35.

Barth, F. (1969). Introduction. In F. Barth (Ed.), Ethnic groups and boundaries. The social organization of culture difference (pp. 9-38). Bergen/Boston: Universitetsforlaget/Little Brown \& co.

Bhabha, K. H. (1994). The location of culture. London: Routledge.

Bojadjieva, A., \& Kushen, R. (Eds.). (2014). Decade intelligence report. Factors for success or failure of Roma inclusion projects. Budapest: Decade of Roma Inclusion Secretariat Foundation.

Bourdieu, P. (1991). Language and symbolic power. Cambridge: Polity Press.

Bourdieu, P., \& Wacquant, L. (1999). On the cunning of imperialist reason. Theory, Culture \& Society, 16(1), 41-58.

Bourdieu, P., \& Wacquant, L. (2001, January/February). NewLiberalSpeak. Notes on the new planetary vulgate. Radical Philosophy, 105, 1-5. Retrieved from http://www.radicalphilosophy.com

Bowker, C. G., \& Star, S. L. (2002). Sorting things out. Classification and its consequences. Cambridge: MIT Press. 
Brubaker, R. (2004). Ethnicity without groups. Cambridge: Harvard University Press.

Brubaker, R., Loveman, M., \& Stamatov, P. (2004). Ethnicity as cognition. Theory and Society, 33(1), 31-64.

Burke, P. (2013). Cultural hybridity. Cambridge: Polity Press.

Callon, M. (1986). Some elements of a sociology of translation: Domestication of the scallops and the fishermen of St Brieuc Bay. In J. Law (Ed.), Power, action and belief: A new sociology of knowledge? (pp.196-223). London: Routledge.

CoE (Council of Europe). (2014, October 29). Towards the creation of a "European Roma Institute". Consultation document prepared by the Council of Europe Secretariat. Strasbourg: Council of Europe.

Filhol, E. (2007). La loi de 1912 sur la circulation des "nomads" (Tsiganes) en France. Revue européenne des migrations internationales, 23(2), 2-20.

FRA, \& UNDP. (2012). The situation of Roma in 11 EU member states. Survey results at a glance. Luxembourg: Publications Office of the European Union. Retrieved from http://fra.europa.eu

Friedman, E. (2014). The situation of Roma between human rights and economics (ECMI Brief \#31). Retrieved from http://www.ecmi.de

Gay y Blasco, P. (2001). "We don't know our descent": How the Gitanos of Jarana manage the past. The Journal of the Royal Anthropological Institute, 7(4), 631-647.

Geertz, C. (1973). The interpretation of cultures. New York: Basic Books, Inc.

Gheorghe, N. (1997). The social construction of Romani identity. In T. Acton (Ed.), Gypsy politics and Traveler identity (pp. 153-171). Hatfield: University of Hertfordshire Press.

Gheorghe, N. (2013). Choices to be made and prices to be paid: Potential roles and consequences in Roma activism and policy-making. In W. Guy (Ed.), From victimhood to citizenship. The path of Roma integration (pp.41-100). Budapest: Kossuth Kiadó.

Giurescu, C. (1943). Studii de istorie socială. Bucureşti: Editura Universul.

Goldscheider, C. (2002). Ethnic categorization in censuses: Comparative observations from Israel, Canada and the United States. In D. I. Kertzer \& D. Arel (Eds.), Census and identity. The politics of race, ethnicity and language in national censuses (pp.71-92). Cambridge: Cambridge University Press.

Hacking, I. (1986). Making up people. In T. C. Heller, M. Sosna, \& D. E. Wellbery (Eds.), Reconstructing individualism: Autonomy, individuality and the self in western thought (pp.222-236). Stanford: Stanford University Press.

Hacking, I. (1995). The looping effects of human kinds. In D. Sperber, D. Premack, \& A. J. Premack (Eds.), Causal cognition: A multidisciplinary debate (pp. 351394). New York: Oxford University Press.
Havas, G. (2002). On sociological studies about Roma. In E. Kállai (Ed.), The Gypsies/The Roma in Hungarian society (pp.18-24). Budapest: Regio-Teleki László Foundation.

Jenkins, R. (1997). Rethinking ethnicity: Arguments and explorations. London: Sage Publications.

Kaluszynski, M. (2001). Republican identity: Bertillonage as government technique. In J. Caplan \& J. Torpey (Eds.), Documenting individual identity: tThe development of state practices in the modern world (pp.123-138). Princeton: Princeton University Press.

Kemény, I. (2000). The structure of Hungarian Roma groups in light of linguistic changes. RegioMinorities, Politics, Society, 1, 105-116.

Kertzer, D. I., \& Arel, D. (2002). Censuses, identity formation and the struggle for political power. In D. I. Kertzer \& D. Arel (Eds.), Census and identity. The politics of race, ethnicity and language in national censuses (pp. 1-43). Cambridge: Cambridge University Press.

Klímová, A. I. (2004). Development and institutionalisation of Romani representation and administration. Part I. Nationalities Papers, 32(3), 599-629.

Klímová, A. I. (2005a). The Romani voice in world politics. The United Nations and non-state actors. Farnham: Ashgate.

Klímová, A. I. (2005b). Development and institutionalisation of Romani representation and administration. Part II: Beginnings of modern institutionalization (nineteenth-century-World War II). Nationalities Papers, 33(2), 155-210.

Klímová, A. I. (2006). Development and institutionalisation of Romani representation and administration. Part 3a: From national organizations to international umbrellas (1945-1970)-Romani mobilization at national level. Nationalities Papers, 34(5), 599-621.

Klímová, A. I. (2007). Development and institutionalisation of Romani representation and administration. Part 3b: From national organizations to international umbrellas (1945-1970)-the international level. Nationalities Papers, 35(4), 627-661.

Klímová, A. I. (2010). Development and institutionalisation of Romani representation and administration. Part 3c: religious, governmental and nongovernmental institutions (1945-1970). Nationalities Papers, 38(1), 105-122.

Kovats, M. (2001). The emergence of European Roma policy. In W. Guy (Ed.), Between past and future: The Roma of central and eastern Europe (pp.93-116). Hatfield: University of Hertfordshire Press.

Kovats, M (2003, July 30). The politics of Roma identity: Between nationalism and destitution. Open Democracy. Retrieved from http://www.opendemocracy.net

Kovats, M (2013). Integration and the politicisation of Roma identity. In W. Guy (Ed.), From victimhood to citizenship. The path of Roma integration (pp.101128). Budapest: Kossuth Kiadó.

Labbé, M. (2009). Statistique ethnique, légitimité poli- 
tique et changement de régime. Critique internationale, 4(45), 9-18.

Ladányi, J., \& Szelényi, I. (2001). The social construction of Roma ethnicity in Bulgaria, Romania and Hungary during market transition. Review of Sociology, 7(2), 79-89.

Latour, B. (2005). Reassembling the social. An introduction to actor-network-theory. New York: Oxford University Press.

Liègeois, J.-P. (1986). Gypsies. An illustrated history. London: Al Saqi Books.

Liègeois, J.-P. (1994). Roma, Tsiganes, Voyageurs. Strasbourg: Conseil de l' Europe.

Liègeois, J.-P. (2007). Roma in Europe. Strasbourg: Council of Europe.

Lipphardt, V., \& Surdu, M. (2014). The genetic construction of Roma groupness and its interdisciplinary entanglements. Unpublished manuscript.

Lucassen, L. (1991). The power of definition, stigmatisation, minoritisation, and ethnicity illustrated by the history of the Gypsies in the Netherlands. The Netherlands Journal of Social Sciences, 27, 80-91.

Lucassen, L. (1998). "Harmful tramps": Police professionalization and Gypsies in Germany, 1700-1945. In L. Lucassen, W. Willems, \& A.-M. Cottaar (Eds.), Gypsies and other itinerant groups: A socio-historical approach (pp.74-93). New York, NY: St. Martin's Press.

Lucassen, L., Willems, W., \& Cottaar, A.-M. (Eds.). (1998). Gypsies and other itinerant groups: A socio-historical approach. New York, NY: St. Martin's Press.

Marushiakova, E., \& Popov, V. (2011). Between exoticization and marginalization. Current problems of Gypsy studies. Behemoth. A Journal on Civilisation, 1, 51-68.

Matei, P. (2010). Raporturile dintre organizaţiile ţigăneşti interbelice şi Biserica Ortodoxă Română. In V. Ciobanu \& S. Radu (Eds.), Partide politice şi minorităţi naţionale din România în secolul XX (Vol. V, pp. 159173). Sibiu: Techno Media.

Matei, P. (2011). Romii în perioada interbelică. Percepţii naţionaliste. In S. Toma \& L. Fosztó (Eds.), Spectrum. Cercetări Sociale despre Romi (pp. 15-41). ClujNapoca: Editura Institutului pentru Studierea Prolemelor Minorităţilor Naţionale/Kriterion.

Mayall, D. (2004). Gypsy identities 1500-2000. From Egipcyans and Moon-men to the ethnic Romany. London and New York: Routledge.

Müller-Hill, B. (1988). Murderous science: Elimination by scientific selection of Jews, Gypsies, and others, Germany 1933-1945. Oxford: Oxford University Press.

Nastasă, L., \& Varga, A. (Eds.). (2001). Minorităţi etnoculturale. Mărturii documentare. Tiganii din România (1919-1945). Cluj-Napoca: Fundaţia CRDE.

Nobles, M. (2002). Racial categorization and censuses. In D. I. Kertzer \& D. Arel (Eds.), Census and identity. The politics of race, ethnicity and language in national censuses (pp.43-71). Cambridge: Cambridge University Press.
Nordenstam, S., \& Ringstrom, A. (2013, September 23). Police database of Roma stirs outrage in Sweden. Reuters. Retrieved from http://www.reuters.com

Okely, J. (1983). The Traveller-Gypsies. Cambridge: Cambridge University Press.

OSCE-ODHIR. (2013). Implementation of the action plan on improving the situation of Roma in the OSCE area: Renewed commitments, continued challenges (Status report). Warsaw: OSCE-ODHIR.

Popova, Z. (2015). "Roma" policy making: key challenges \& possible solutions (ECMI Brief \#34). Retrieved from http://www.ecmi.de

Prieto-Flores, O., Puigvert, L., \& Santa Kruz, I. (2012). Overcoming the odds: Constricted ethnicity in middle-class Roma. Identities: Global studies in Culture and Power, 19(2), 191-209.

Robbin, A. (2000). Administrative policy as symbol system: Political conflict and the social construction of identity. Administration and Society, 32(4), 398-431.

Rövid, M. (2011). One-size-fits-all Roma? On the normative dilemmas of the emerging Roma policy. Romani Studies, 5(21), 1-22.

Rughiniş, C. (2011). Quantitative tales of ethnic differentiation: Measuring and using Roma/Gypsy ethnicity in statistical analyses. Ethnic and Racial Studies, 34(4), 594-619.

Rughiniş, C. (2012). Măsurarea sociologică. Teorii şi practici ale cuantificării. laşi: Polirom.

Said, E. (1978). Orientalism. New York: Pantheon.

Schneeweis, A. (2015). Communicating the victim: nongovernmental organizations advocacy discourses for Roma rights. Communication, Culture \& Critique, 8(2), 235-253.

Sigona, N., \& Trehan, N.(2009). Introduction: Romani politics in neoliberal Europe. In N. Sigona \& N. Trehan (Eds.), Romani politics in contemporary Europe: Poverty, ethnic mobilization, and the neoliberal order (pp.1-23). Basingstoke: Palgrave Macmillan.

Sigona, N., \& Vermeersch, P. (2012). Editors' introduction. The Roma in the new EU: Policies, frames and everyday experiences. Journal of Ethnic and Migration Studies, 38(8), 1189-1193.

Simhandl, K. (2006). "Western Gypsies and TravellersEastern Roma: The creation of political objects by the institutions of the European Union. Nations and $\mathrm{Na}$ tionalism, 12, 97-115.

Simon, P. (2007). "Ethnic" statistics and data protection in the Council of Europe countries: Study report. Strasbourg: Council of Europe. Retrieved from http://www.libertysecurity.org

Simonovits, G., \& Kezdi, G. (2013). The sorting into ethnic identities: Social status and Roma identification in Hungary. Budapest: Hungarian Academy of Sciences. Retrieved from http://www.mtakti.hu

Sobotka, E. (2001). They have a dream. The state of Roma affairs in the Czech Republic. Central Europe Review, 3(18). Retrieved from http://www.ce- 
review.org/01/18/sobotka18.html

Spivak, G. C. (1987). In other worlds: Essays in cultural politics. New York: Methuen.

Spivak, G. C. 1988. Can the subaltern speak? In C. Nelson \& L. Grossberg (Eds.), Marxism and the interpretation of culture (pp. 271-313). Urbana: University of Illinois Press.

Stewart, M. (1997). The time of Gypsies. Oxford: Westview Press.

Stewart, M. (2013). Roma and Gypsy "ethnicity" as a subject of anthropological inquiry. Annual Review of Anthropology, 42, 415-432.

Surdu, M. (in press). Expert frames. Scientific and policy practices of Roma classification. Budapest: CEU Press.

Templer, B. (2006). Neoliberal strategies to defuse a powder keg in Europe: the "Decade of Roma inclusion" and its rationale. New Politics, X-4(40). Retrieved from http://newpol.org

Timmer, D. A. (2010). Constructing the "needy subject": NGO discourses of Roma need. PoLAR, 33(2), 264-281.

Tremlett, A. (2014). Making a difference without creating a difference: Super-diversity as a new direction for research on Roma minorities. Ethnicities, 14(6), 830-848.

UNDP (United Nations Development Programme). (2002). Avoiding the dependency trap. Bratislava: UNDP. Retrieved from http://hdr.undp.org

UNDP. (2005). Faces of poverty, faces of hope. Vulnerability profiles for "Decade of Roma Inclusion" countries. Bratislava: UNDP.

Van Baar, H. (2012). Socio-economic mobility and neoliberal governmentality in post-socialist Europe: Activation and the dehumanisation of the Roma. Journal of Ethnic and Migration Studies, 38(8), 1289-1304.

Vermeersch, P. (2005). Marginality, advocacy, and the ambiguities of multiculturalism: Notes on Romani ac- tivism in Central Europe. Identities: Global Studies in Culture and Power, 12, 451-478.

Vermeersch, P. (2006). The Romani movement: Minority politics and ethnic mobilization in contemporary Central Europe. Oxford: Berghahn Books.

Vermeersch, P. (2012). Reframing the Roma: EU initiatives and the politics of reinterpretation. Journal of Ethnic and Migration Studies, 38(8), 1195-1212.

Verzár, F., \& Weszeczky, O. (1921). Rassenbiologische Untersuchungen mittels Isohämagglutinen. Biochemische Zeitschrift Bd., 126(4), 33-39.

Weber, M. (1978). Economy and society. An outline of interpretative sociology (F. Kolegar, Trans.). Berkeley: University of California Press (Original work published 1922).

Widmann, P. (2007). The campaign against the restless: Criminal biology and the stigmatization of the Gypsies, 1890-1960. In R. Stauber \& R. Vago (Eds.), The Roma: A minority in Europe (pp.19-29). Budapest: CEU Press.

Willems, W. (1997). In search of the true Gypsy: From enlightenment to final solution. London: Frank Cass.

Willems, W., \& Lucassen, L. (2000). Gypsies in the diaspora? The pitfalls of a biblical concept. Histoire Sociale/Social History, 33(66), 251-269.

World Bank. (2000). Roma and the transition in Central and Eastern Europe: Trends and challenges. Washington, DC: World Bank.

World Bank. (2002). Poverty and ethnicity. A crosscountry study of Roma poverty in Central Europe (World Bank Technical Paper no. 531). Washington, DC: The World Bank.

World Bank. (2005). Roma in an expanding Europe: Breaking the poverty cycle. Washington, DC: World Bank.

\section{About the Authors}

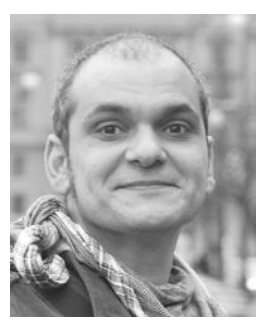

\section{Dr. Mihai Surdu}

In 2014 Mihai Surdu was a postdoctoral research fellow at the Max Planck Institute for the History of Science, Berlin and previously a fellow of the Open Society Roma Initiatives, Budapest. He holds a $\mathrm{PhD}$ in Sociology from the University of Bucharest and he was researcher at the Research Institute for Quality of Life, Bucharest. Surdu published extensively in topics related to educational policies targeting Roma. His more recent interests include history of science and Roma categorization by academics, policymakers and mass-media with a forthcoming book on these themes.

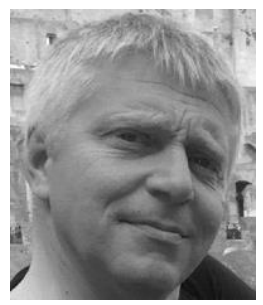

\section{Dr. Martin Kovats}

Martin Kovats has been studying the emergence of Roma as a political phenomenon for twenty years. He has held fellowships at the University of Birmingham and Corvinus University, Budapest and taught at Birkbeck College, University of London. Between 2010 and 2014 he was special advisor the EU Commissioner for Employment, Social Affairs and Inclusion. 